\title{
Two Seed-borne Double-stranded RNA Viruses, Beet Temperate Virus and Spinach Temperate Virus
}

\author{
Tomohide Natsuaki*, Shuichi Yamashita**, Yoji DoI**, \\ Seiichi OKudA*, and Michiaki TeranAKA*
夏秋知英* ・山下修一**・土居養二**・奥田誠一*・寺中理明*：2 種の種子伝染性二本鎖
RNA ウイルス，フダンソウ潜伏ウイルスおよびホウレンソウ潜伏ウイルス

Key Words : seed-borne virus, dsRNA virus, beet temperate virus, spinach temprate virus.

Several seed-borne "temperate" viruses, including beet temperate virus (BTV) and spinach temperate virus (STV), have been detected in Japan ${ }^{1,2}$. These viruses closely resemble to radish yellow edge virus $(\mathrm{RYEV})^{3)}$, beet cryptic virus $(\mathrm{BCV})^{4)}$ and carnation cryptic virus $(\mathrm{CCV})^{5)}$ in the following points: (1) isometric virus particles about $30 \mathrm{~nm}$ in diameter, (2) low concentration in infected plants which usually show no symptoms and (3) high frequency of seed transmission and untransmissibility by mechanical inoculation. Furthermore $\mathrm{RYEV}^{6)}$ and $\mathrm{CCV}^{7)}$ have been known to contain segmented double-stranded ribonucleic acid (dsRNA). This note describes the nucleic acids and some properties of BTV and STV.

Transmissibility of $\boldsymbol{B T V}$ and $\boldsymbol{S T V}$ For estimation of seed transmission, dip preparations from midribs ob cotyledons were examined in an electron microscope. BTV particles were detected in over $90 \%$ seeds of leaf beet (Beta vulgaris var. cicla). STV particles were detected in $80-100 \%$ seeds of spinach (Spinacia oleracea cvs. Nihon-Oba, Seiyo-Oba and Heianhiyoshimaru). Attempts were unsuccessful to transmit BTV and STV by mechanical inoculation of crude sap from infected leaves or partially purified preparations to Cucumis sativus, Nicotiana glutinosa, N. tabacum (Samsun and White Burley), Vigna sesquipedalis, Gomphrena globosa, Chenopodium amaranticolor, and C. quinoa.

Properties of $\boldsymbol{B T V}$ BTV was purified from infected frozen leaves by clarifying sap extracted in $0.1 \mathrm{M}$ phosphate buffer ( $\mathrm{pH} 8.0$ ) containing $0.1 \%$ thioglycolic acid with $40 \%$ vol 1:1 chloroform-butanol, followed by three cycles of differential, and

* Faculty of Agriculture, Utsunomiya University, Mine-machi, Utsunomiya 321, Japan 宇都宮 大学農学部

** Faculty of Agriculture, University of Tokyo, Bunkyo-ku, Tokyo 113, Japan 東京大学農学部

1) Natsuaki, T., Yamashita, S., Doi, Y. and Yora, K. (1979). Ann. Phytopath. Soc. Japan 45: 84.

2) Natsuaki, T., Yamashita, S., Doi, Y. and Yora, K. (1981). Ibid. 47:94. 3) Natsuaki, T., Yamashita, S., Doi, Y. and Yora, K. (1979). Ibid. 45: 313-320. 4) Kassanis, B., White, R. F. and Woods, R.D. (1977). Phytopath. Z. 90: 350-360. 5) Lisa, V., Luisoni, E. and Milne, R. G. (1981). Ann. appl. Biol. 98: 431-437. 6) Natsuaki, T. ,Yamashita, S., Doi, Y., Okuda, S. and Teranaka, M. (1983). Ann. Phytopath. Soc. Japan 49: 593-599. 7) Lisa, V., Boccardo, G. and Milne, R. G. (1981). Virology 115: 410-413. 


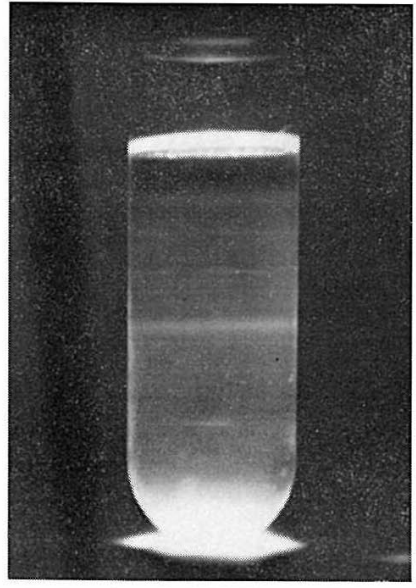

Fig, 1. A band of BTV particles formed by sucrose density gradient centrifugation.

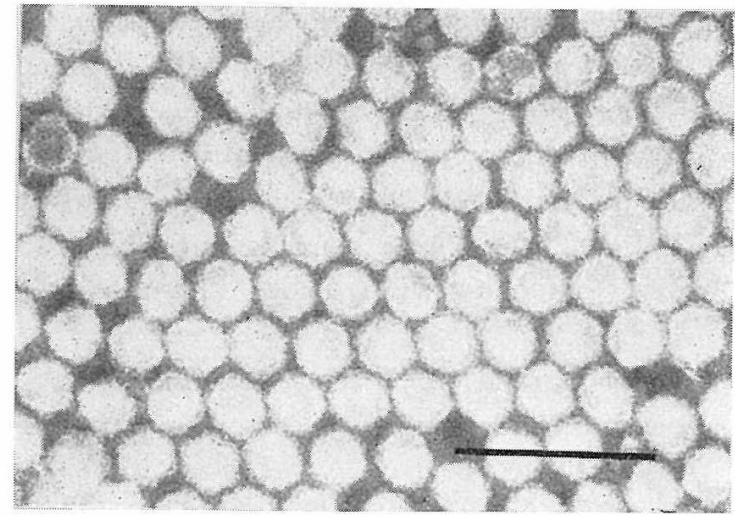

Fig. 3. Purified BTV particles stained with $2 \%$ phosphotungstate pH6. Bar represents 100 nm.

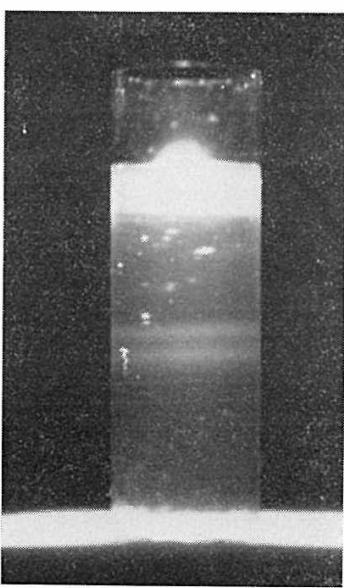

Fig. 2. Two bands of BTV particles formed by $\mathrm{CsCl}$ equilibrium density gradient centrifugation.

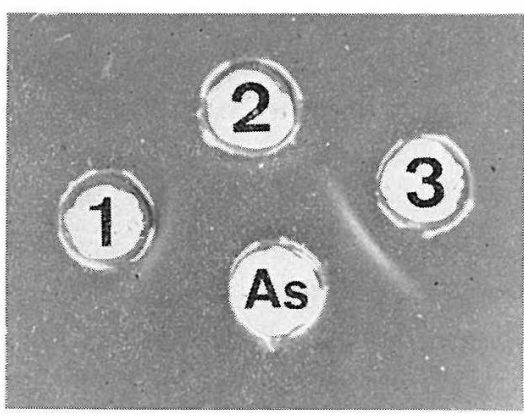

Fig. 4. Gel immunodiffusion test: central well contained poly (I) : poly (C) antiserum diluted to $1: 2$ (As), the rest contained RYEV dsRNA (1), BTV nucleic acid (2), rice dwarf virus (RDV) dsRNA (3).

then $10-40 \%$ linear sucrose density gradient (for $2.5 \mathrm{hr}$ at $68,900 \times \mathrm{g}$ ) and $35 \% \mathrm{w} / \mathrm{v}$ $\mathrm{CsCl}$ equilibrium density gradient (for $20 \mathrm{hr}$ at $117,800 \times \mathrm{g}$ ) centrifugations. BTV particles were sedimented through the sucrose gradient as a single band (Fig. 1). Two close bands were formed in $\mathrm{CsCl}$ with buoyant densities ranging from 1.37 to $1.38 \mathrm{~g} / \mathrm{cm}^{3}$ (Fig. 2), both of which contained intact virus particles (Fig. 3) and no differences could be found by electron microscopic observation. The sedimentation coefficient of BTV measured by analytical centrifugation was 115-122 S. The nucleic acid of BTV, prepared by the method as described previously $y^{4}$, reacted with poly(I): poly(C) antiserum ${ }^{4}$ (Fig. 4). In $5 \%$ polyacrylamide gel electrophoresis (PAGE) the nucleic acid migrated as four bands (Fig. 5) with estimated mol. wts of about 1.45 , $1.28,0.65$ and $0.56 \times 10^{6}$, using rice dwarf virus dsRNA ${ }^{8)}$ as marker. These indicate that BTV contains segmented dsRNA. BTV did not react with antisera to RYEV

8) Reddy, D. V.R., Kimura, I. and Black, L. M. (1974). Virology 60:293-298. 


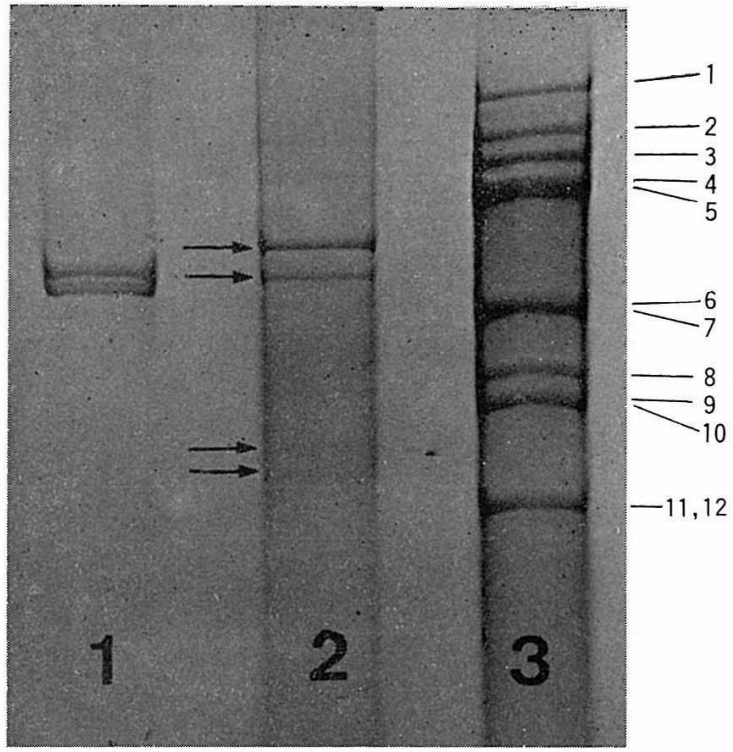

Fig. 5. Electrophoresis of BTV dsRNA in $5 \%$ polyacrylamide slab gel: (1) RYEV dsRNA; (2) BTV dsRNA showing four species (arrows); (3) RDV dsRNA as marker, MW $3.10 \times 10^{6}(1), 2.50 \times 10^{6}(2), 2.25 \times 10^{6}$ (3), $1.90 \times 10^{6}(4), 1.80 \times 10^{6}(5), 1.15 \times 10^{6}$ (6), $1.13 \times 10^{6}(7), 0.86 \times 10^{6}(8), 0.78 \times 10^{6}$ (9), $0.75 \times 10^{6}(10), 0.52 \times 10^{6}$ (11 and 12$)$.

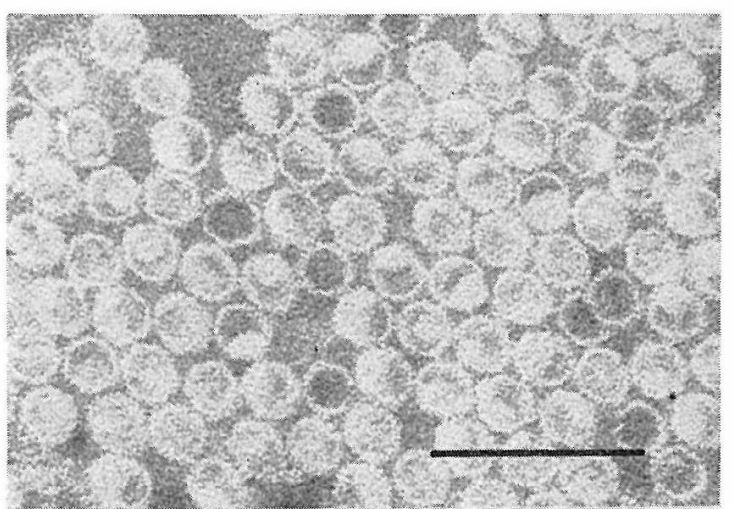

Fig. 6. STV particles in partially purified preparation. Bar represents $100 \mathrm{~nm}$.

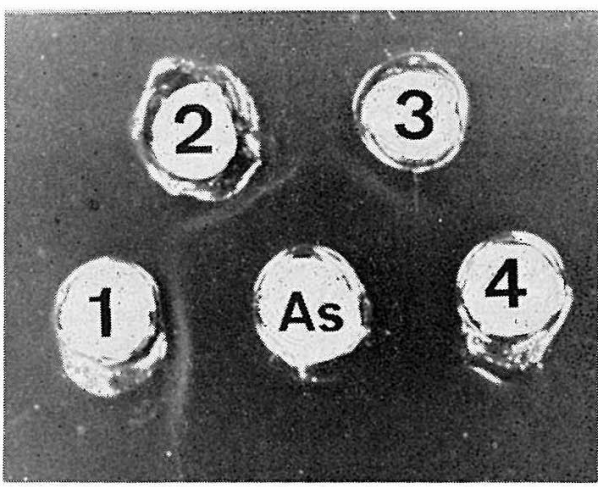

Fig. 7. Gel immunodiffusion test: central well contained poly(I): $\operatorname{poly}(\mathrm{C})$ antiserum diluted to $1: 2$ (As), the rest contained RDV dsRNA (1), RYEV dsRNA (2), STV nucleic acid (3), cucumber mosaic virus single-stranded RNA (4). 


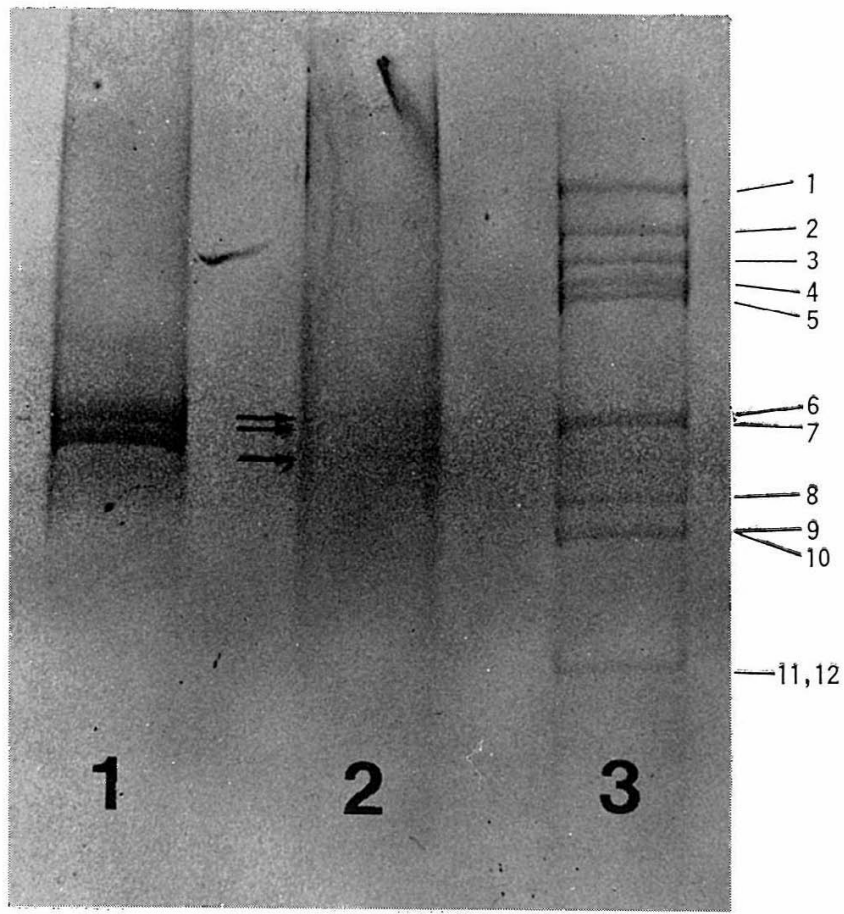

Fig. 8. Electrophoresis of STV dsRNA in $5 \%$ polyacrylamide slab gel: (1) RYEV dsRNA ; (2) STV dsRNA showing three species (arrows); (3) RDV dsRNA as marker (MW of 1-12 shown in Fig. 5).

and BCV. BTV is very similar to BCV in host plant species, buoyant density in $\mathrm{CsCl}$ and sedimentation coefficient, suggesting that BTV is a strain of BCV. However, the nucleic acid of BTV is segmented dsRNA, whereas that of BCV has not been reported yet.

Properties of STV STV was partially purified by a method described for BTV except that $\mathrm{CsCl}$ centrifugation was omitted. Since no bands were visible in sucrose density gradient centrifugation, fractions were examined under an electron microscope. The fractions containing STV particles (Fig. 6) were stored as partially purified preparation and used to prepare the nucleic acid. The nucleic acid of STV reacted with poly(I): poly $(\mathrm{C})$ antiserum (Fig. 7). In 5\% PAGE the nucleic acid gave three bands with estimated mol. wts of about $1.31,1.21$ and $1.10 \times 10^{6}$ (Fig. 8). These indicate that STV contains segmented dsRNA. STV also did not react with antisera to RYEV and BCV.

Because there are differences in molecular weight distribution of dsRNA among BTV, STV, RYEV and CCV, it is indicated that these four viruses are independent from each other. It seems that they constitute a new plant virus group of isometric seed-borne dsRNA viruses. 